Federal Reserve Bank of Minneapolis

Research Department

\title{
The Origins of the Monetary Union in the United States
}

\author{
Arthur J. Rolnick, Bruce D. Smith \\ and Warren E. Weber*
}

Working Paper 504

Revised August 1993

*Rolnick, Federal Reserve Bank of Minneapolis; Smith, Federal Reserve Bank of Minneapolis and Cornell University; and Weber, Federal Reserve Bank of Minneapolis. We wish to thank Ed Green, Jeffrey Rogers Hummel, Preston Miller, Steve Russell, Pierre Siklos, Dick Sylla, Dick Todd, and especially Neil Wallace for their comments on an earlier draft of this paper. The views expressed herein are those of the authors and not necessarily those of the Federal Reserve Bank of Minneapolis or the Federal Reserve System. 


\section{INTRODUCTION}

Monetary unions, areas in which a single, uniform money is used or exchange rates are fixed, have been the subject of much debate in recent years. The formation of at least one monetary union is being discussed in Europe, and the dissolution of another is being considered in the former Soviet Union. Yet, despite the recent debates, the gains to be had from a monetary union are still at best vaguely articulated, and the problems of maintaining and enforcing a monetary union seem to be similarly vaguely stated. While theoretical analyses and empirical explorations using recent data can shed some light on these issues, examination of historical experiences with different monetary systems is also illuminating. In this paper we examine the historical experience of the United States during the colonial, Revolutionary, and Confederation periods.

Although it may seem odd to think of the United States as having had to create a monetary union, it did not have one during its formative years. Each colony or state had the power to-and many did-issue their own paper currencies. These currencies were fiat monies, monies which are irredeemable and intrinsically useless, and circulated against specie and each other at market determined exchange rates. This system had been in place in some form since 1690 .

In 1787 , the Constitution fundamentally changed the monetary system in the United States. State issue of fiat monies was prohibited and, it can be argued, an attempt was made to establish a monetary union. Here we examine why such a change in the monetary system was made. We argue that monetary unification was viewed as being desirable because it was a method of resolving problems created by costly exchange rate variability and as necessary because it eliminated a problem with seigniorage.

Our argument proceeds as follows. First, we show that exchange rate variability was an important feature of the monetary environment of the United States prior to 1787. Further, we show that this variability was viewed as being costly. Since these costs could have been avoided simply 
by fixing exchange rates between the currency issues of the different states, we proceed to explain why state currency issues were prohibited. We argue that simply fixing exchange rates between different state currencies would not have been enough, for it would have left a problem with seigniorage. In particular, it would have left any state with the power to levy an inflation tax on the other members of the monetary union. Historical experience prior to 1787 had established that this power would be used by at least some states and its use would be detrimental to monetary union. The elimination of state powers of money creation addressed what we call the seigniorage incentive problem.

Our analysis is based on a particular approach to thinking about multiple fiat monies. It considers different fiat monies to be intrinsically perfect substitutes. ${ }^{1}$ This approach has two important implications that lead to our views about the monetary changes made in the Constitution. The first is that exchange rate variability is unnecessary in the sense that it has social costs that can be avoided. The second is that a seigniorage incentive problem is necessarily present in any system with multiple fiat monies.

An alternative approach to multiple fiat monies treats different monies as limited substitutes (possibly for transactions reasons). In this approach, there are well-defined demand functions for different moneys. As a result, exchange rate fluctuations would likely be caused by changes in economic fundamentals like preferences, technologies, and government policies. We argue that this approach does not successfully explain the United States experience and cannot explain why the Constitution prohibited states from issuing their own fiat monies.

Thus, one of the findings of our study is that viewing multiple monies as limited substitutes is less useful than viewing them as perfect substitutes. We think that this result does not only apply to the historical analysis of the United States but to the analysis of modern day monetary unions as well. 


\section{MULTIPLE CURRENCIES AND EXCHANGE RATE FLUCTUATIONS}

In this section we set the historical stage for our discussion by describing monetary arrangements during the colonial, Revolutionary, and Confederation periods. ${ }^{2}$ We document that the fiat monies issued by the various colonies and states fluctuated in value against specie and each other. In the next section, we document some of the problems that this exchange rate variability created.

\section{The Colonial Period}

In 1690 Massachusetts issued the first colonial irredeemable paper currency. It was used to pay troops when tax revenue was insufficient. Eventually each of the 13 colonies issued fiat money called bills of credit. ${ }^{3}$

The colonies issued bills of credit in two general ways. One was to create a "loan office," print money, and lend it at interest. While this money was not redeemable in specie, most enabling legislation for such emissions required currency issues to be retired as loans were repaid: in some colonies these provisions were more and in some colonies less strictly adhered to. The interest on loans was used to fund general expenditures. In colonies with weil-run loan offices, interest income often financed all peacetime expenditures, and taxes were only levied in wartime.

The other way of issuing bills of credit was simply to print it and use it in payment for government expenditures. In all colonies enabling legislation for this type of currency issue also included provisions for future taxes to be used to retire the currency. Again, some colonies actually levied such taxes and engaged in this currency retirement, and some did not. Colonies that followed this practice, or retired currency issued on loan, had currencies that maintained a relatively stable value. However, some colonies were lax in either collecting taxes involved in currency retirement, or diverted these revenues to other uses. For such colonies seigniorage income was an important 
source of revenue. In colonies that continually relied on seigniorage, there was typically currency depreciation. ${ }^{4}$ As we will see, these colonies also created problems for their neighbors.

When a colony issued fiat money it was issued in the colony's unit of account. The result was that payments to the colony made in fiat money of a certain face value were equivalent to whatever amount of specie was implied by the legal unit of account. However, this valuation did not fix an exchange rate in either of two senses: colonies did not enforce this exchange rate in private transactions, ${ }^{5}$ and the colonies did not exchange their bills of credit for specie at this rate (as a fixed exchange rate regime would require).

In practice the fiat money of different colonies circulated against specie, and against each other at market determined rates. Extensive data on the behavior of the exchange rates between London and the individual colonies have been collected by McCusker (1978). For instance, (despite having the same unit of account) Pennsylvania and Delaware currencies exchanged against each other at a variable rate, with Delaware currency at discount which "regularly ranged between 5 and 10 percent" (McCusker 1978, p. 182). Similarly, Virginia and Massachusetts' currency prices varied. For example, in 1761 Virginia currency appreciated 14.4 percent against Massachusetts' currency and then depreciated 6.4 percent and 9.7 percent in 1762 and 1763, respectively (McCusker 1977, pp. 142,211$)$. In general, the McCusker data implies variable exchange rates among all the colonial currencies.

\section{The Revolutionary War Years}

During the Revolutionary War years, there was an even greater variety of fiat monies than there was during the colonial period. As is generally well known, the newly established federal government relied heavily on fiat money and the seigniorage income that resulted. In addition, many states continued the practice of issuing fiat money. According to Nevins $(1927$, p. 481$)$, all told "the specie value of the currency issued by the States during the Revolution was estimated by Jefferson 
in 1786 at $\$ 36,000,000$, or just as much as the specie value of the Continental (federal) currency." And, while systematic time series data on exchange rates is lacking, it is clear that exchange rates fluctuated among these various monies.

\section{State Currency Issues}

The states issued their own irredeemable currencies during the Revolution, and as in the colonial period, the depreciation of these currencies were not uniform. Some state currencies depreciated greatly. For instance, "South Carolina's paper by the final year of fighting was almost worthless, and it became necessary for Governor Rutledge . . to suspend the laws making it a legal tender" (Nevins 1927, p. 488). In 1781 Virginia exchanged newly issued loan certificates with a face value of $\$ 1$ for $\$ 1,000$ of its previously issued currency. In 1781 North Carolina rated $\$ 200$ of paper currency to $\$ 1$ specie; in 1782 this rating was revised to 800 to 1 . The depreciation of Maryland's currency seems modest by comparison: Maryland redeemed its earliest paper money issues at the rate of 40 to 1 (Nevins 1927, p. 486).

Some other state currencies held their value much better. Pennsylvania is an example. In March 1780 Pennsylvania issued " $£ 100,000$ upon the security of lands in Philadelphia and of Province Island, all belonging to the State-the security causing the bills to be called "island money"

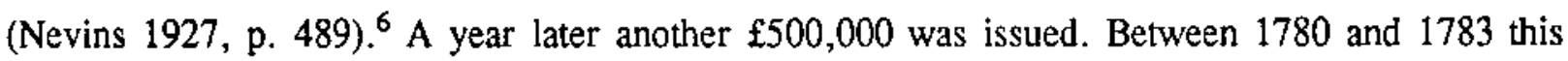
currency exchanged at anywhere from 1.25 to 1 to 5 to 1 in terms of specie (Bezanson 1951, Appendix, Table 4). It was thus one of the least depreciated paper issues of the Revolution.

The states also issued circulating certificates of various sorts in addition to their explicit issues of fiat money. North Carolina, for instance, issued five different kinds of certificate debt over the period $1778-1782$, with a nominal value in excess of $\$ 40,000,000$. Some of these certificates bore a fixed nominal interest rate, some bore interest and were indexed to the value of specie, and some bore no interest. Some also had a special status in certain kinds of payments to the state, while 
others did not. The result was that the relative values of different types of certificates varied (see Morrill 1969, for a more complete discussion). In addition, the states issued loan certificates, which were analogous to federal loan certificates which we describe below.

\section{Federal Currency Issues}

When the Revolutionary War began, the federal government had no power to tax. It was forced to rely on loans, requisitions from state governments and currency issues to meet its revenue needs. However, loans provided little income, and the legality of the state governments was often poorly established. Even when their legality was established, the states had little in the way of a tax collection apparatus in place. Thus, states' own revenue collections were not large and they were reluctant to pass what they did collect on to the Continental Congress. As a result, the federal government had to rely mostly on irredeemable paper money (the so-called Continentals) and other forms of closely related debt to finance its expenditures. Indeed, from 1775 through 1779 , money creation accounted for 82 percent of the federal government's income (Ferguson 1961, pp. 43-44).

The proliferation of Continentals that permitted this seigniorage revenue to be raised is well known, as is their depreciation. The Continental Congress issued over $\$ 226,000,000$ of Continentals between June 1775 and the end of 1779 , after which it ceased all issues. ${ }^{7}$ Just as in the colonial period, people felt that an important component of imparting value to the currency was to make it acceptable for tax payments at a fixed rate in terms of specie. Since the Continental Congress had no powers of taxation, it requested that the states make Continentals acceptable for taxes. Although the legislation that authorized the first issue of Continentals provided for them to be retired with taxes collected from the states, such legislation did not accompany later issues. Further, state retirements of Continentals through taxation were very limited.

The depreciation of the Continentals was severe. In January $1777, \$ 1.25$ Continental was required to purchase $\$ 1.00$ in specie. By January $1781, \$ 100$ Continental was required to obtain 
$\$ 1.00$ in specie. Because of this depreciation, Continental issues ceased late in 1779 , and, according to Ferguson (1961), the Continental ceased to circulate as a currency by the spring of 1781 .

In addition to the Continentals, Congress financed its expenditures by selling loan certificates. These paid interest and were issued in minimum denominations of $\$ 200$. Loan certificates sold at face value for Continentals, and like Continentals they were not redeemable for specie. By 1781 about $\$ 60,000,000$ had been "subscribed." Not all subscriptions were voluntary, however, since loan certificates were sometimes paid out directly for supplies (Ferguson 1961, pp. 53-55). Loan certificates also held their value better than Continentals, as one might expect from the fact that they were issued in relatively large minimum denominations. ${ }^{8}$ Because loan certificates were a superior store of value to Continentals, they came to be used as "a kind of mercantile currency" (Ferguson 1961, p. 40). Thus the federal government was simultaneously issuing multiple currencies, which did not depreciate at the same rate.

Another type of federal government certificate, which had been in use since 1776, were drafts drawn on various departments of the government. Certificates "were issued by all the departments in lieu of money ... ." At first merely handwritten notes, they later became printed forms. "From the beginning they were connected with impressment" (Ferguson 1961, p. 57), so they were exchanged (involuntarily) for supplies. Ferguson (1961, p. 63) estimates that "the certificates issued by federal officers must have approximated, in nominal amount, the entire sum of Continental currency." The certificates were irredeemable, bore no interest, and were issued in fixed nominal amounts. They apparently tended to be of even less value than Continentals (Ferguson 1961, p. 65n), although Nevins (1927, p. 505) asserts that "it was often difficult, in practice, to distinguish between the certificates and paper money ... ." And, in fact, the certificates did serve certain functions of money, since they were accepted by some states for taxes after February 1780 . The Continental Congress began accepting them from the states in payment of certain requisitions after March 1780 . 
The last wartime issues of the federal government occurred in 1782 when Congress decided to convert "unliquidated" public debts into a "liquidated" public debt. To this end it appointed federal commissioners to inspect claims against the federal government. "The commissioners verified claims and revalued them in specie if they were stated in terms of depreciated currency. For balances due they issued 'final settlement certificates' amounting to over $\$ 3,700,000$ " (Ferguson 1961, p. 179). ${ }^{9}$ Final settlement certificates, though, were also used in government payments. For instance, about $\$ 11,000,000$ (in specie value) of final settlement certificates were issued in troop payments.

\section{Confederation}

Relative to the colonial period there were additional complications with the monetary system under Confederation. The first came from the array of liabilities the country inherited from the Revolution-some state and some federal. The retirement of this inherited debt was a problem that interacted with and compounded other monetary problems. In addition, much of this debt circulated, adding to the uncertainty regarding the value of various circulating liabilities.

The second complication arose from new monies that circulated along with the old. Under the Articles of Confederation, from 1783 to 1789 , states, like their forerunners, were allowed to issue their own irredeemable paper money. And to a large extent, certain states reestablished the monetary arrangements that they had employed in the colonial period. ${ }^{10}$ The Federal government was also permitted to issue money and did so to help finance its debt service. (Fiat money also played a significant role in permitting some states to service their debts.)

The third complication stemmed from a major deflation. After the massive inflation of the Revolution, prices in Pennsylvania had returned to the levels of $1771-73$ by 1786 (Bezanson 1951, p. 174). This deflation prompted agitation for money issues to which some states responded and some did not. 


\section{State Currency Issues}

The combination of a large inherited Revolutionary War debt and a major deflation posed a significant problem for the states. The real value of the claims against them was large and rising, and the problems of debt service and retirement were severe. Further, in 1782 the Continental Congress stopped the payment of interest on all federal loan certificates. Many states assumed the responsibility for paying the interest on these certificates held by their own residents.

Some states (Massachusetts being the most prominent example) sought to raise the required revenue entirely through direct taxation. The result was high tax rates, and an eventual tax rebellion (Shay's rebellion).

Other states attempted to use the power of money creation to address the situation. Such payments were made with irredeemable state-issued liabilities. For instance, Pennsylvania gave public creditors "certificates of interest," and made these certificates receivable for state tax payments. According to Ferguson (1961, p. 222), Pennsylvania "created in the process a kind of state money." New Jersey also issued "revenue money" to its public creditors, and other states would have done so in the absence of other federal action, which we describe below.

These currency issues added to those already in existence from the Revolution. Thus, by early 1785 it was estimated that Pennsylvania had more than $£ 160,000$ in circulation. ${ }^{11}$ In March 1785 , Pennsylvania authorized an emission of an additional $£ 100,000$ "to pay interest on all public securities held by citizens of the state ..." (Ferguson 1961, p. 229). Taxes and revenues from the sales of public lands were pledged to retire these issues. ${ }^{12}$ Thus Pennsylvania sought to finance debt service by the temporary creation of money. In addition, the state created a loan office along colonial lines, emitting $£ 50,000$ for this purpose. All Pennsylvania currency issues were made receivable at face value for all payments to the state. 
“From May 1781 . . . until 1790, state paper, which at times depreciated mildly, again became the medium in daily use ${ }^{n}$ in Pennsylvania (Bezanson 1951, p. 326). According to Bezanson (Appendix, Table 4), the ratio of Pennsylvania state currency values to specie fluctuated between 1.05 and 1.12 in 1786 , between 1.10 and 1.75 in 1787 , between 1.43 and 1.56 in 1788 , and between 1.13 and 1.43 in 1789 . Thus, while Pennsylvania currency held its value relatively well by the standards of the time, holders of its currency were subject to considerable exchange rate risk.

In 1786 New Jersey supplemented the "revenue money" it had issued to pay interest on inherited debt by emitting $£ 100,000$ through a loan office. To promote the acceptance of the currency, New Jersey implemented a set of taxes to be used to retire it, a law making it legal tender for public and private debts, and penalties for discriminating between it and specie in transactions. According to Ferguson (1961, p. 244), "New Jersey's legal tender bills were fairly steady [in value], although they passed outside the state at a slowly increasing discount." In particular, New Jersey's paper currency had a more stable value internally than it did in either New York city or Philadelphia-a fact which led to political tension between New Jersey and its neighbors. "New Jersey's tender provisions could not be enforced in the neighboring states, and consequently depreciation began in both Philadelphia and New York . . . Before long, the depreciation in the neighboring states affected the Jersey currency's value at home" (Kaminski 1972, pp. 119-20). Nor was this depreciation uniform. Within its own borders, "in nonspeculative ventures," (Kaminski 1972, p. 124) New Jersey currency went at a discount against specie of between 7 and 15 percent. As early as May 1787 it was at a 12 to 18 percent discount in New York, however. The analogous discount in Philadelphia at the same date was 11 to 20 percent. In 1788 New Jersey currency was discounted by only 7 percent in New York, but by 33 percent in Philadelphia. By 1789 , the discount was 33 percent in both New York and Philadelphia. (See Kaminski 1972, p. 125.) 
New York also issued fiat money in 1786 which held its value relatively well, but nevertheless appeared to experience some depreciation. In that year New York issued $£ 50,000$ for the purpose of paying the interest on outstanding debt (that is, it was engaged in a form of currency finance),

and in addition issued another $£ 150,000$ through a loan office. The money

was made a legal tender for private debt only in the case of suits .... By the end of the year even the opponents of the paper issue had to admit that the credit of the bills was good. They fluctuated in value, and at times were at a discount of as much as 10 percent, but they remained a valid circulating medium. In midsummer of 1787 it was boasted that they were 'universally received upon a par with gold or silver' . . . (Nevins 1927 , p. 528. See also Kaminski 1972, pp. 155, 158.)

South Carolina may have had the most stable currency during this period. South Carolina had exchanged its own state debt for federal debt held by its own citizens, so that during Confederation virtually all debt held in South Carolina was state debt. The interest on this debt was paid by state issues of "special indents". Ferguson $(1961$, p. 233) estimates that "the actual emission of indents varied from $\$ 273,000$ to a $\$ 535,000$ annually." (See Higgins 1969 for annual emissions.) ${ }^{\mathbf{1 3}}$ These certificates were redeemed out of tax revenue. In addition, $£ 100,000$ was issued through a loan office emission in 1786. "The paper held its value. Such was its success that in 1789, when specie dollars were pouring into Charlestown it was preferred as being more convenient to use" (Nevins 1927, pp. 526-27).

The fiat monies of Pennsylvania, New Jersey, New York, and South Carolina fluctuated in value relative to specie, and hence fluctuated in value relative to each other. In the cases of New York and South Carolina in particular these fluctuations relative to specie appear to have been 
relatively small. This was not the case for the currencies of Rhode Island and North Carolina, which experienced more sustained and dramatic depreciation.

In 1786 Rhode Island issued $£ 100,000$ through a loan office. After some initial depreciation, the state passed measures imposing penalties for discriminating in transactions between specie and the state currency, which was also made a legal tender for private debts. Provisions were established which "enabled any debtor to discharge his debt by depositing the required sum with the county judge, who should give notice of the fact in the press" (Nevins 1927, p. 229). Thus creditors were prevented from avoiding payment in Rhode Island currency via the expedient of simply avoiding their debtors.

Rhode Island's currency depreciated rapidly. According to Ferguson (1961, p. 243) it circulated at one-tenth of its face value by 1788 , and to Nevins (1927, p. 540) at one-twelfth of its face value by 1789 . Finally, "in the autumn of 1789 , the Legislature repealed the law making the bills a legal tender at par, and fixed the value at which it should be received by creditors, in satisfaction of awards in lawsuits, at one-fifteenth the value of specie" (Nevins 1927, pp. 540-41). Thus, not only did Rhode Island currency depreciate markedly relative to specie, but also relative to the currencies of the other states as well.

In North Carolina, the certificates issued during the Revolution were accepted for property tax payments through 1786. Different kinds of certificates had varying legal valuations for tax payments, so that even the state did not treat its liabilities as having a uniform value. In addition, in 1787,1788 , and 1789 property tax acts levied two distinct types of taxes; one to be paid in currency or specie, and the other to be paid in certificates. The objective of levying a tax payable only in certificates was to encourage them to circulate (Morrill 1969, p. 42).

To supplement the certificates (and partly to replace them), North Carolina issued another currency. In $1783, \mathfrak{f 1 0 0 , 0 0 0}$ pounds was issued; and in 1785 , another $£ 100,000$ was issued. The 
money was a legal tender for all public and private debts. "All confiscated [Tory] property was to be set aside exclusively as a fund to redeem the new currency ... . [However] the 1783 Assembly failed to establish procedures by which the confiscated property was to be sold to redeem the currency, and . . later Assemblies blocked such enabling legislation" (Morrill 1969, p. 59). And, in fact, by 1789 only $£ 21,848$ had been retired (Morrill 1969, p. 93).

The currency issued by North Carolina quickly "depreciated to an average of about 25 percent off specie in the purchase of commodities and then stabilized at about 12.5 percent to 15 percent off nominal value when exchanged for hard money" (Morrill 1969, p. 70). This depreciation was largely complete by late in 1783 , “after which time the paper's value remained practically steady for two years" (Morrill 1969, p. 71). However, by the end of 1785, the state's currency "slipped from about 25 percent off nominal value to perhaps 35 percent off par, while in exchange for specie the currency declined from about 15 percent off par to about 25 percent off nominal value." (Morrill 1969 , p. 75 .) By 1786 , the paper was about 33 percent below specie, and was 40 percent below by 1787. In 1789 , it reached 50 percent of nominal value, where it remained well into the next decade. ${ }^{14}$ (Morrill 1969, pp. 87-92.)

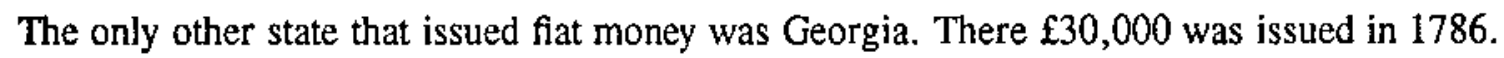
According to Kaminski (1972), this went at a one-third discount by 1789 . The other states remained "hard money states," despite substantial political agitation for fiat money in some cases.

\section{Federal Currency Issues}

It has already been noted that in 1782 the federal government stopped paying interest on federal loan certificates. In 1784 interest payments on these certificates were resumed by the use of the following system. Certificates of interest, or 
indents were printed by the [federal] treasury and deposited with the loan offices in each state, who turned them over to the local authority. The states were supposed to issue interest due on public securities .... Congress had the notion that indents would flow freely across state borders and be taken indiscriminately by all states for taxes. Since they were printed in small denominations, ranging from one to twenty dollars, they would provide a national circulating medium (Ferguson 1961, p. 224).

During the years 1786 to 1789 between $\$ 703,000$ and $\$ 1,364,000$ of indents were outstanding.

The indent system, which was in place throughout the Confederation period, was meant to be a simultaneous solution of two problems: it constituted a means for financing debt service via a kind of money creation, and it was intended to provide a uniform medium for interstate transactions. ${ }^{15}$ This indicates some interest in the problem of creating a uniform currency on the part of Congress. However, Congress could not force the states to accept indents in a uniform way for tax payments, and in fact the value of indents varied from state to state depending, in part, on how they were received by any state in payments. According to Ferguson (1961, p. 228), indents ultimately passed at between one-eighth and one-fourth of their face value, depending on location. ${ }^{16}$

\section{THE COSTS OF EXCHANGE RATE VARIABILITY}

During its formative years, the United States experienced two problems which the framers of the Constitution in 1787 attempted to overcome. The first of these was a proliferation of fiat monies accompanied by a great deal of exchange rate variability. We now present some examples of how such variability increased the cost of trade.

\section{Example 1: Virginia 1755-64}

Colonial monetary affairs were subject to British oversight. Over time the monetary relations between Britain and the colonies became an increasing source of frictions. Such frictions came to a 
head between Britain and Virginia between 1755 and 1764. The result was the Currency Act of 1764, which forbade the colonies to make their own currency a legal tender for public or private debts. ${ }^{17}$

Virginia was the last colony to issue fiat money. When it first issued bills of credit in 1755, the colony was desperately short of specie. (See Ernst 1973 and Brock 1975.) Colonists who borrowed from English merchants, which was a widespread practice, had incurred sterling denominated debts. These debts were routinely (and of necessity) repaid in local currency, which was in fact a legal tender. But, of course, the rate of exchange between Virginia currency and sterling was subject to some fluctuations. ${ }^{18}$

Given the legal tender status of Virginia's currency, British creditors could not avoid repayment in this form. However, British creditors objected strenuously to being subjected to exchange rate risk. In 1758, British merchants petitioned the crown demanding "absolute protection against any fluctuations in the rate of exchange. Such risks were to be born by the Virginians alone" (Ernst 1973, p. 52). Thus the allocation of exchange rate risk becarne a subject of heated political discussion.

In response to British pressure, Virginia law was amended in 1755 "to allow courts of record to settle all executions for sterling debts in local currency-paper as well as coin-at a 'just' rate of exchange. A just rate was taken to be the actual rate at the time of court judgment" (Ernst 1973, p. 54). This became the common legal practice.

However, even this was viewed as inadequate protection against exchange rate variation by British creditors. Virginia law allowed an exchange rate to be set at the time of legal settlement, but British merchants desired protection against exchange rate variation between the time of settlement and the time of payment. British merchants wanted the option of consenting "to accept paper money 
in amounts they deemed necessary for the purchase of sterling bills of exchange to the original and full value of sterling debts" (Ernst 1973, p. 52).

This was unacceptable to Virginia. In addition to forcing Virginians to bear all exchange rate risk in exchange with Britain, it would give British merchants bargaining power over Virginians who had only local currency as a means of payment. ${ }^{19}$ Thus an impasse was reached, leading to the Currency Act of 1764 . This act prevented the colonies from making their own currencies a legal tender in public or private payments.

The issue of who was to bear exchange rate risk in the colonial period became a major bone of political contention between Britain and the colonies. Of course the same issue was present between the colonies themselves, but here the colonies had little freedom of independent action. One method for improving matters would have been to create (or to attempt to create) a uniform North American currency. Such a proposal was in fact made by Benjamin Franklin in 1765, and a similar proposal had been made Britain in 1763 . Indeed, the Stamp Act was originally intended to raise funds to support a uniform North American currency. Thus, even at this early date, interest in creating a uniform currency manifested itself on both sides of the Atlantic. But some time was to elapse before this actually occurred.

\section{Example 2: Confederation}

During the Revolution, and continuing into the period of Confederation, interstate commerce was of growing importance. ${ }^{20}$ This fact suggests the desirability of a medium of exchange to be used in interstate transactions. One possibility was specie. However, its usefulness for this purpose was reduced by the fact that it seems often to have passed by weight. Another possibility would have been indents; as we have seen, this was intended by Congress. However, the value of indents was not uniform across states. A third possibility was to make use of the various state currencies in interstate transactions. That this did, in fact, occur is indicated by the observation that Pennsylvania 
currency circulated in "Maryland, central Virginia, and the Ohio Valley; and North Carolina currency [circulated] in western Virginia and Kentucky" (Schweitzer 1989, p. 315). Nevertheless, the use of the state currencies in interstate transactions (as well as at home) was plagued by exchange rate uncertainty.

Consider the problems with Pennsylvania's currency, a currency which maintained its value far better than that of some other states. According to Bezanson (1951, p. 326), "in the spring of 1789 James Cox explained 'the very fluctuating state that our paper money has always been in, makes it difficult to ascertain the value of it at different periods." An illustration of the perceived costs of this exchange rate variability is the fact that the Pennsylvania assembly refused to be paid in Pennsylvania currency, which was a legal tender for public, but not private, debts (Kaminski 1972, p. 70).

An even more dramatic illustration is offered by the attitude of the Bank of North America toward Pennsylvania currency. The Bank of North America, chartered in 1781, had successfully circulated its bank notes for several years. In an effort to dissuade the state from issuing fiat money, the Bank announced that it would refuse to accept Pennsylvania currency (at any discount) in transactions. Not only did this not dissuade the state, it led to a revocation of the Bank's charter by Pennsylvania. In an effort to regain its charter, the Bank yielded and offered to receive state currency on deposit, "provided these paper transactions were kept 'entirely distinct and separate' from the specie accounts" (Kaminski 1972, p. 64). This the Bank did, keeping accounts in Pennsylvania currency completely distinct from specie accounts, even though the state's currency did not initially depreciate. The Bank actually did receive a substantial quantity of state currency, and the keeping of separate accounts led to a "considerable extra expense to the Bank" (Kaminski 1972, p. 67). Apparently this was a cost the Bank was willing to absorb in order to avoid exchange rate risk. (Recall that Pennsylvania currency fluctuated in value, rather than depreciating uniformly.) 
New Jersey faced a similar problem with its currency. Nevins (1927) makes the point that four systems of legal valuation of specie were in place among the different states and then argues that

. . these difficulties were accentuated by the total unreliability of the paper currencies. It was hard for even well-informed citizens to understand what value to attach to a handful of bills, and the tables of exchange between states would have filled a fat volume . . . A man could not be sure that what was sound money in one county would pass when he crossed an imaginary line, nor that if his bills did pass, he would not be charged a ruinous discount (pp. 569-70).

Some of the costs this exchange rate uncertainty imposed are illustrated by the problems that New Jersey's Governor Livingston had in making transactions out of state:

[The Governor, who] naturally did much business in New York city, found it so impossible to use Jersey money "at the unconscionable discount which your brokers and merchants exact" that he collected what New York money was due him and saved it to employ across the Hudson (Nevins 1927, p. 569).

Even in South Carolina, whose currency had a fairly stable value, exchange rate fluctuations between different kinds of circulating liabilities imposed costs. In Higgins' (1969, p. 127) description All financial transactions were difficult and unstable when there was little specie and the value of the various monetary substitutes was either unknown or unpredictable. The Revolutionary bonds, and the interest certificates which came from the South Carolina treasury annually, served as a circulating medium, but they were limited in use. Although the notes could be transferred by endorsement, negotiations were difficult as the value of a certificate and the amount of any given transaction were not identical. 


\section{THE SEIGNIORAGE INCENTIVE PROBLEM}

The second problem that the United States faced, and that the Constitution's framers attempted to address, was a seigniorage incentive problem. This problem is that-when possiblegovernments will attempt to collect seigniorage from citizens outside their jurisdiction, and thereby redistribute revenue to their own citizens. ${ }^{21}$ With this power being exercised, neighboring states (colonies) have an incentive to retaliate, however. One possible form of retaliation is to impose legal restrictions limiting the use of the offending state's currency or promoting the use of the "domestic money." But such restrictions undermine the uniformity of the currency, potentially lead to exchange rate variability, and cause a welfare loss due to the implied restrictions on interstate trade.

This situation arose in New England during the colonial period. The problem reemerged under Confederation. We now discuss these two episodes.

\section{Colonial New England}

By 1710 all of the New England colonies had issued their own currencies. The respective currencies easily crossed colonial borders. Even though there was no government attempt to fix exchange rates officially or to enforce or sanction the practice, "the bills of the several New England colonies customarily, although not always, passed current in all the rest at a uniform value" (Brock 1975 , p. 35). In other words, the exchange rates among the currencies of these colonies were constant at a rate of one-to-one. This constancy of exchange rates implies, in turn, the potential for any one colony to levy the inflation tax on its neighbors. Countries with money stocks growing faster than the average can collect seigniorage from residents of countries with money stocks growing less rapidly than average under such an exchange rate regime.

This potential did not go unexploited in New England. Here Rhode Island was the culprit: "the fact that Rhode Island bills circulated widely in other colonies permitted her to levy tribute on 
her neighbors" (Brock 1975, p. 39). Between 1710 and 1744 the New England money supply grew at any average rate of almost 8 percent per year; over the same period the supply of Rhode Island bills of credit grew at an average rate of almost 14.5 percent per year. Most of this increase went into circulation in other colonies: "it was estimated that as many as five-sixths of the Rhode Island bills were absorbed by Massachusetts" (Brock 1975, p. 41). By 1744, 43 percent of the New England money supply had been issued by Rhode Island, which had only about 10 percent of New England's population.

Given the high rate of inflationary taxation levied by Rhode Island on its neighbors, it is not surprising that constant exchange rates did not persist (although it may be a testament to the costs of exchange rate uncertainty that they lasted as long as they did). In 1749 Governor Hutchinson of Massachusetts proposed the retirement of the colony's own paper currency, after which "no person should receive or pay within the province bills of credit of any of the other governments of New England. ${ }^{22}$ In 1749 Massachusetts passed a law prohibiting the circulation of other New England currencies within its border, with a fine of 50 pounds for a violation.

Connecticut took similar action to prohibit the circulation of Rhode Island currency. In February 1747 (or 1748, the date is unclear), citizens of Norwich, Connecticut petitioned the colonial assembly, "The Rhode Islanders have the Last Fall Sapped our Interest by buying up $\mathrm{w}^{\text {th }}$ Their pernicious bills our best provisions . . [ [, ] and are now out buying up our Cows \& best Stock [,] what They can with Those same pernicious bills." (quoted by Brock, p. 314). Merchants in New Haven noted the same effect, "that the colony of Rhode Island by the present Large unequal proportion of outstanding bills are Enabled Annually to buy off A great part of the product of this Colony the Labour of an Industrious people, to the no Small Detriment of the Inhabitants of this colony" (quoted by Brock, p. 314f). 
In May 1752 the Connecticut assembly did prohibit the circulation of Rhode Island bills emitted after 1750 . Thus, the monetary union that had been (unintentionally) achieved in New England had broken down.

\section{Confederation}

The seigniorage incentive problem is not limited to regimes in which exchange rates are constant or fixed. It recurred during the Confederation period when some states attempted to collect seigniorage from their neighbors by issuing irredeemable paper money accompanied by legal-tender laws. Again, the neighboring states retaliated by imposing legal restrictions that prohibited the use of the "foreign money" within their borders. "The [resulting] want of a uniform currency created financial and commercial difficulties that were prolific of ill-feeling among citizens of the different states" (Nevins 1927, p. 568).

One attempt to extract seigniorage income in this way occurred in New England, and again the primary culprit was Rhode Island. It was the only one of the New England states to create a fiat money, and its currency depreciated rapidly. In opposing Rhode Island's currency emission, some of the merchants of Newport and Providence argued that "a paper money law . . . would ruin Rhode Island's commerce with other states, which would not accept payment for their goods in rag money" (Nevins 1927, p. 228). Not only did Rhode Island nonetheless emit a currency; it made it impossible for creditors to its citizens to insist on payment in any other form. The result was a legal retaliation by Massachusetts and Connecticut, who "passed laws enabling their citizens to pay all debts owed to people of a paper-tender state in just the same manner as the latter paid their debts to the citizens of Massachusetts and Connecticut. That is, Rhode Island creditors were virtually outlawed in the neighboring states ..." (Nevins 1927, p. 571). Thus credit transactions between citizens of Rhode Island and citizens of Connecticut or Massachusetts were impaired due to Rhode Island's attempt to force the use of its currency in debt payments. 
The seigniorage incentive problem also recurred in North Carolina. There some merchants who were within-state creditors might have been expected to oppose the creation of a depreciating currency which was legal tender for private debts. However, a "factor that qualified the [negative] attitude of some merchants [to the state's currency] was that while they were creditors to many persons, they themselves were debtors to other merchants of the state and, more often, to mercantile interests outside North Carolina. A number of North Carolina merchants, in fact, came to dare their out-of-state creditors to sue for recovery in the postwar fiat currency" (Morrill 1969, pp. 64-65). And indeed, so eager was North Carolina to force circulation of its currency by making it a legal tender for private debts "that judges would not allow the nominal value of the currency to be altered even with the consent of the debtor and creditor involved in the case . ." (Morrill 1969, p. 86). Similarly, "with Virginia merchants particularly in mind, legislators at the 1786 Assembly introduced a bill that would have made it a misdemeanor to demand specie payment for merchandise, to refuse to accept paper money in payment, or to accept paper money at less than nominal value" (Morrill 1969 , p. 89).

The problems this would create were, of course, anticipated by opponents of legal-tender currency. Some such opponents predicted "that the lack of confidence in the currency and in the government of the state would further decrease the flow of commerce into the ports of North Carolina” (Morrill 1969, p. 80). And, indeed, neighboring states took some retaliatory action. "When Georgia sold her confiscated property, the Legislature ordered that no currency of other states be accepted" (Nevins 1927, p. 570). This action was viewed in North Carolina as particularly aimed at it. However, Virginia, and South Carolina merchants were also refusing to accept North Carolina currency. This limited the ability of North Carolina to levy an inflation tax on residents of Virginia, which had no currency of its own, or South Carolina, which had a currency with a stable value. 
These episodes represent another illustration of the seigniorage incentive problem. Even though for both North Carolina and Rhode Island the exchange rate between their currencies and specie varied, seigniorage was still an issue. Both states forced residents of neighboring states to accept their currencies in payment of debts at unfavorable rates of exchange. To the extent they were successful, this redistributed resources to their own citizens and also enhanced their ability to levy inflationary taxation on other states.

\section{A SOLUTION TO THE SEIGNIORAGE PROBLEM}

In this section we explore the extent to which Article 1 , Section 10 of the United States' Constitution can be interpreted as an attempt to solve the exchange rate variability and seigniorage incentive problems. This article states:

No State shall . . coin money; emit bills of credit; make anything but gold or silver a tender in payment of debts; pass any bill of attainder, ex post facto law, or law impairing the obligation of contracts . . . .

In particular, we focus on the provision of this section which seems to form a monetary union by eliminating the possibility of states issuing their own individual currencies.

There are two mutually exclusive perspectives that one could use to understand how this provision in the Constitution solved these problems. These perspectives differ in their views of the degree of substitutability between the different currencies in use.

The first perspective assumes that currency substitution is quite limited; different currencies are viewed as imperfect substitutes for transactions purposes. According to this view, there are well defined demand functions with the usual properties for different currencies. Moreover, exchange rate fluctuations-under this view-would likely be the result of fluctuations in the economic fundamen- 
tals-preferences, endowments, technologies, and government policies-that determine currency demands and supplies.

This perspective does not help us understand the Constitutional prohibition of state currency issues, however. First, it does not necessarily explain why the Constitution would have contained any provisions that attempted to limit exchange rate variability. In particular, it is unclear that this view implies that it is desirable to eliminate the exchange rate variability that arises due to variability in fundamentals. For instance, Lucas (1982) displays an economy where fundamental exchange rate fluctuations are fully consistent with Pareto optimality.

Second, and more important, even granting that this view could explain why eliminating exchange rate variability was desirable, it does not explain why the prohibition of state currency issues was necessary in order to do so. This perspective would imply that exchange rate variability could have been eliminated simply by requiring the states to fix their exchange rates against a common currency (say a federal currency, or alternatively, sterling). Moreover, to the extent that the individual states were "small," this arrangement would have solved the seigniorage incentive problem because it would have eliminated any state discretion with respect to raising seigniorage revenue. Indeed state money supplies would have been fully determined by the necessity of maintaining the fixed exchange rate. Thus, simply fixing exchange rates would have eliminated both the exchange rate variability and the seigniorage incentive problems.

Finally, it is not clear that this viewpoint can confront basic observations from the period under consideration. For instance, it is not at all apparent how imperfect substitutability between currencies can be reconciled with the constancy of New England exchange rates before 1750 .

The alternative perspective is that different fiat monies are intrinsically perfect substitutes. Such a viewpoint motivates the work by Kareken and Wallace (1981) and King-Wallace-Weber (1992). Kareken and Wallace (KW) display a model in which agents choose among currencies solely 
on the basis of their real returns. In such a model, KW show that exchange rates among fiat monies are indeterminate in the sense that any unchanging exchange rate between two currencies is consistent with a perfect foresight equilibrium. (Notice that this explains the experience of colonial New England.) When the exchange rate between two currencies does not change, they will have the same rates of return, and agents will be indifferent as to which of the currencies they hold. ${ }^{23}$ King-Wallace-Weber (KWW) modify the KW analysis to allow for uncertainty. In the KWW economy, agents choose among currencies based on their rate of return distributions. They show that exchange rate indeterminacy extends to a large class of random processes for exchange rates, where the randomness is nonfundamental. ${ }^{24}$

Such "sunspot" fluctuations in exchange rates are unnecessary in the sense that the social costs they impose could be eliminated with fixed exchange rates or a uniform currency. KWW demonstrate that when there is not complete participation in markets for hedging exchange rate risk, the randomness in exchange rates is costly because it carries over to real wealth and consumption. Because this exchange rate risk is unrelated to preferences, technologies, or government policies and can be eliminated, it represents an unnecessary social cost. It is always possible to find lump sum taxes and transfers that will support an equilibrium with constant exchange rates, consumption, and real wealth. When at least some agents are risk averse, this equilibrium will be Pareto superior to the equilibrium with fluctuating exchange rates.

According to this perspective, requiring the states to fix their exchange rates against a common currency would have eliminated exchange rate variability but it would not have eliminated the seigniorage incentive problem. Kareken and Wallace show that, with perfectly substitutable currencies, a fixed exchange rate regime places no particular restrictions on the rate of growth of any state's money supply. By implication, then, no restrictions are placed on the ability of an individual state to raise seigniorage revenue. 
The KW result implies that if the countries in a monetary union have the individual ability to issue money, then they also have the ability to use money creation to collect seigniorage from residents of other countries. In an equilibrium with unchanging exchange rates between monies, countries with money stocks growing faster than the average will collect seigniorage from residents of countries with money stocks growing less rapidly than the average. If this ability is exercised, then those countries bearing the tax may choose to retaliate in any one of several ways. They could increase their own rate of money creation as a way of "collecting back" seigniorage income. The result might be high inflation, diluting the benefits of a monetary union. Or, alternatively, controls on the use of "foreign" currency might be imposed to limit its use, and thereby to limit how much seigniorage revenue other countries can raise at the expense of the domestic country. Such controls, however, work against a monetary union; they reduce the substitutability of currencies, but substitutability is the essence of a monetary union.

Thus, a fixed exchange rate regime may be difficult to maintain unless institutional arrangements are made to mitigate the seigniorage incentive problem. Prohibiting individual entities within the union from issuing money, as the United States did in its constitution, is one such arrangement.

\section{OTHER EXPLANATIONS FOR THE PROHIBITION OF STATE FIAT MONIES}

The formative years of the United States help illustrate why a monetary union is desirable, yet difficult to maintain. Exchange rate variability was significant and costly during these years. But the experience with different colonies and states trying to export inflation and tax their neighbors suggests why a monetary union could not have been maintained simply by requiring the states to fix exchange rates.

Our position is that the newly formed country's desire to create a lasting monetary union was at least partly responsible for the constitutional prohibition on the power of states to issue currency 
(bills of credit). Moreover, the prohibition on state currency issues would seem-at least superficially - to have resolved seigniorage incentive problems by eliminating altogether the power of the states to generate seigniorage. We are not the first to try to explain the willingness of states to give up the power to issue money. Nevertheless, we feel other explanations are either unconvincing or cannot stand on their own. In this section we briefly review and critique other explanations that have been proposed for the Constitutional prohibition of state currency issues.

One popular explanation for the prohibition of state currency issues is the memory of the depreciation of the Continental. According to this view, the losses that many incurred were still deeply ingrained in people's memories and people were simply opposed to the creation of state currencies, which had always been of the inconvertible paper variety. This view appears explicitly in Calomiris (1988), but is certainly implicit or explicit in a variety of other literature.

We think there are reasons to doubt that this is a complete explanation for the Constitutional prohibition of state currencies. First, this explanation suggests that the federal government should have been prohibited from issuing bills of credit. But this prohibition, while considered, was not enacted. Second, the Confederation period witnessed deflations as large as the wartime inflation in states that had issued fiat money (for instance, Pennsylvania). Third, if this explanation accounted for opposition to state currencies, how and why did seven states issue inconvertible paper monies during Confederation? And fourth, this explanation does not account for why the Federalist Papers (p. 226) refers only to "the loss which America has sustained since the peace [our emphasis] from the pestilent effects of paper money; . . . that is, there is no reference to problems that arose during the Revolution.

A second explanation of the Constitutional prohibition of state-issued bills of credit has been offered by Nevins (1927) and Schweitzer (1989a). They have argued that a combination of state issues of currency and legal tender laws were disruptive of (particularly interstate) commerce. Under 
this view, it is suggested that some states (colonies) issued currency, which they allowed to depreciate, and passed laws preventing creditors in other states from extracting payment in any other form from within-state debtors. To the extent that this practice was followed, it would have acted as a tax on various kinds of interstate commerce accomplished via credit extension. Of course what enforced the use of depreciated state currency issues were legal tender laws passed by the states, causing Schweitzer (1989a, p. 320) to conclude that "it was the damage of legal tender laws to interstate relations, rather than . . the memory of the Continental, that resulted in a prohibition of state paper money."

Indeed, we have seen that Rhode Island and North Carolina in particular issued fiat money, which depreciated, and made it a legal tender for private debts. This certainly was attended by some retaliation by other states, and was disruptive of interstate commerce. Thus Nevins (1927, p. 569) could argue that "the worst state disputes connected with currency arose from the enactment of measures impairing the obligation of contracts . . . They were the making of depreciated paper a legal tender for debts . . ." Similarly, Schweitzer (1989a, p. 318) could assert that "many believed that tender laws were increasingly causing friction between states," and could (p. 319) quote Madison to the effect that fiat money "is producing the same warfare and retaliation among the states as were produced by the state regulations of commerce."

While we believe that this explanation helps explain why states agreed to give up the power to emit bills of credit, we do not think it is a complete explanation. In particular, if interference with private contracts was the problem, the Constitution could have simply prohibited (as it did) the states from making anything but gold and silver a legal tender for private debts. This was in fact recognized at the Constitutional Convention, as it was a point raised by Madison in debate (Elliot's Debates, p. 445). 


\section{CONCLUSION}

In conclusion, we believe there are obvious gains from having a monetary union. ${ }^{25}$ However, a monetary union in which fiat money can be issued at the discretion of the individual members gives rise to an incentive problem: members of the union can gain seigniorage income at the expense of other members. The only way to address this problem is either to find an acceptable way to share seigniorage among the members or to prevent members from issuing currency. The United States chose to take this latter approach when in 1787 it adopted a constitution that prohibited states from issuing their own currency.

The United States' attempt at creating a monetary union raises an obvious question that we do not address in this paper: Did the actions taken by the United States in 1787 result in a monetary union in the sense that exchange rates were constant among the various monies circulating in the country? In the sequel to this paper we argue that the answer is no. Unresolved seigniorage incentive problems plus a loophole in the system regarding bank creation and regulation prevented the United States from achieving a monetary union at least until the late 1800 s. In the sequel, we also identify the mechanisms by which monetary union was finally achieved. 


\section{FOOTNOTES}

${ }^{1}$ Different fiat monies are intrinsically perfect substitutes because, by definition, they have no intrinsic value. Any piece of paper can be used in exchange as well as any other piece of paper. Of course if governments impose legal restrictions favoring the use of one kind of money over another, the monies will cease to be perfect substitutes. (See Wallace 1983 for a discussion.) This situation is inconsistent with a uniform currency.

During the period we examine, there were several attempts by governments to impose legal restrictions limiting the substitutability of different colonial/state fiat monies. We argue below that these were reflections of the seigniorage incentive problem that arises with multiple fiat currencies.

${ }^{2}$ Also see Sylla (1982) for an overview of some of the issues we discuss.

${ }^{3}$ Prior to the creation of paper money, the colonies had made use of externally minted specie. However, each colony (although it minted no specie of its own) defined a colonial unit of account. This unit was measured in pounds, shillings, and pence of the colony in question, and each colony defined its unit of account to be a certain quantity of Spanish milled dollars. Thus a pound in Pennsylvania meant something different than a pound in South Carolina; throughout we will use the term pound to apply to the colony in question.

${ }^{4}$ For a discussion of different colonial experiences see Ferguson (1953), Ernst (1973), Brock (1975), McCusker (1978), Smith (1985a,b, 1988), Wicker (1985), or Perkins (1992). Smith (1985a,b) provides an explanation for how temporary monetization of deficits was consistent with stable currency values.

${ }^{5}$ In fact some colonial laws prohibited the legal valuation from being enforced in preference to the market rate of exchange.

${ }^{6}$ It bears emphasis that the legal valuation of pounds in the different states varied considerably. In Georgia a Spanish dollar was valued at 5 shillings, in New England and Virginia at 6 
shillings, in New York and North Carolina at 8 shillings, in South Carolina at 321/2 shillings, and elsewhere at 71/2 shillings. See Nevins (1927), p. 481.

${ }^{7}$ This figure is from Ferguson (1961). It is an estimate; slightly different figures can be found cited by other authors.

${ }^{8}$ See, for instance, Bryant and Wallace (1984).

${ }^{9}$ The latter refers to specie value.

${ }^{10}$ See, for example, Schweitzer (1989) or Ferguson (1961, p. 244), who argues that during Confederation "the various states were reenacting their particular experience with paper money in colonial times."

${ }^{11}$ Recall that the term "pound" did not mean the same thing in different states. We use the term "pound" to refer to the currency of the state in question. See Footnote 4 for the legal meaning of the term "pound" as used in the different states.

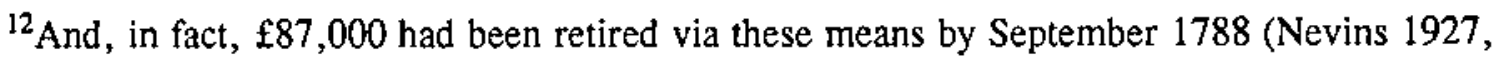
p. 522).

${ }^{13}$ “ The South Carolina pound has been stated in terms of dollars at the rate of $\$ 4.286$ to $\mathfrak{f 1}$, which the legislature adopted in 1783" (Ferguson 1961, p. 233).

${ }^{14}$ The state's currency continued to circulate for some time after the ratification of the Constitution. The Constitution prohibited the issue of new state currency, but did not require the retirement of old state currency issues.

${ }^{15}$ For further evidence that indents circulated see Bolles (1884, pp. 324, 326).

${ }^{16}$ In addition to these instruments, specie coined abroad was in general circulation. How important specie was as a component of the money supply is a confused topic. For instance, Nevins (1927, pp. 516-17) asserts a general scarcity of specie in the United States from 1782 or 1783 into 1785. On the other hand, Massey (19??, p. 65) says "it has been estimated that some $\$ 10$ million 
in coins of all types moved into circulation in 1782 and $1783 . "$ He then claims specie exports were large between 1783 and 1785 , after which "coins began to return to circulation." In any event, specie was present, and its value too was uncertain. Clipping of coins was a common practice, and "all coin passed by weight and not by face value ... . The United States Government in 1782 actually had Timothy Pickering clip a quantity of French guineas which had come over as a loan .... If the Government paid them out as they were, the first takers would clip them and reap a snug profit ..." (Nevins 1927, p. 569). The inefficiencies in exchange of using coins that had to pass by weight are, of course, apparent.

${ }^{17}$ More specifically, the colonies not covered by the Currency Act of 1751 , which applied to New England.

${ }^{18}$ These fluctuations, in Virginia's case, were hardly dramatic. See McCusker (1978) or Smith (1985a).

${ }^{19}$ If Virginians had been forced to bear all exchange rate risk, one can ask what the "incidence" of this "tax" might have been. In particular, goods prices and/or interest rates might have adjusted to compensate them (partially) for bearing this risk. Whatever its incidence, however, any departure from optimal risk sharing represents a source of inefficiency. Moreover, British creditors were apparently willing to bear whatever price adjustments resulted in order to shed their exposure to exchange rate risk.

${ }^{20}$ For some quantification of the importance of interstate trade see Bjork (1963).

${ }^{21}$ For other discussions of the seigniorage incentive problem in monetary unions see Casella and Feinstein (1989) and Zarazaga (1991).

${ }^{22}$ Quoted by Brock (1975), pp. 249-50.

${ }^{23}$ There is an issue as to whether the exchange rate indeterminacy result of Kareken-Wallace applies when one or more of the currencies is to be retired. It certainly applies if currency is only 
retired "asymptotically," which is not an implausible description of the events we have described. It is also possible to produce methods of retirement which deliver an indeterminacy result even if the currency is retired in finite time.

${ }^{24}$ See also Shell (1977), Azariadis (1981), and Cass and Shell (1983) for a discussion of the related notion of a sunspot equilibrium.

${ }^{25}$ We do not mean to imply, however, that every "country" should become part of a global monetary union, even if institutional arrangements can be found to mitigate the seigniorage problem. The reasons countries may not find it in their interest to be part of the same monetary union are suggested by Canzoneri and Rogers (1990). In their analysis a fixed exchange rate regime is optimal only if agents in the countries belonging to it have roughly similar preferences for collecting revenue through seigniorage. Seigniorage preferences may differ due to different preferences for government spending or different abilities to collect revenue from sources other than money creation. 


\section{REFERENCES}

Azariadis, Costas. 1981. Self-fulfilling prophecies. Journal of Economic Theory 25 (December): $380-96$.

Behrens, Kathyryn L. 1923. Paper Money in Maryland: 1727-1789. Johns Hopkins University Studies in Historical and Political Science, Series 41, No. 1.

Bezanson, Anne. 1951. Prices and inflation during the American Revolution: Pennsylvania, 1770-1790. Philadelphia: University of Pennsylvania Press.

Bjork, Gordon C. 1963. Stagnation and growth in the American economy, 1784-1792. Ph.D. Thesis: University of Washington.

Bolles, Albert. 1884. The financial history of the United States, from 1774 to 1789, vol. 1, 4th edition. New York: D. Appleton and Co. (reprinted in 1969 by Augustus M. Kelley).

Brock, Leslie V. 1975. The currency of the American colonies, 1700-1764: A study in colonial finance and imperial relations. New York: Arno Press.

Bryant, John, and Wallace, Neil. 1984. A price discrimination analysis of monetary policy. Review of Economic Studies 51 (April): 279-88.

Calomiris, Charles W. 1988. Institutional failure, monetary scarcity, and the depreciation of the continental. Journal of Economic History 48 (March): 47-68.

Canzoneri, Matthew B., and Rogers, Carol Ann. 1990. Is the European community an optimal currency area? Optimal taxation versus the cost of multiple currencies. American Economic Review 80 (June): 419-33.

Cass, David, and Shell, Karl. 1983. Do sunspots matter? Journal of Political Economy 91 (April): 193-227.

Casella, Alessandra, and Feinstein, Jonathan. 1989. Management of a common currency. In $A$ European central bank? Perspectives on monetary unification afier ten years of the EMS, ed. 
Marcello de Cecco and Alberto Giovanni, pp. 131-56. Cambridge: Cambridge University Press.

Commission of the European Communities. 1990. One market, one money: An evaluation of the potential benefits and costs of forming an economic and monetary union. Luxembourg: Office for Official Publications for the European Communities.

Ernst, Joseph A. 1973. Money and politics in America: $1755-1775$. Chapel Hill: University of North Carolina Press.

Feldstein, Martin. 1992. Europe's monetary union: The case against EMU. The Economist 324 (June 13): $19-22$.

Ferguson, E. James. 1953. Currency finance: An interpretation of colonial monetary practices. William and Mary Quarterly, 3rd series, 10: 153-80.

1961. The power of the purse: $A$ history of American public finance, 1776-1790. Chapel Hill: University of North Carolina Press.

Hamilton, Alexander; Madison, James; and Jay, John. 1787. The Federalist papers (reprinted 1982). New York: Bantam.

Higgins, W. Robert. 1969. A financial history of the American Revolution in South Carolina. Ph.D. dissertation: Duke University.

Kaminski, John Paul. 1972. Paper politics: The northern state loan offices during Confederation. Ph.D. dissertation: University of Wisconsin.

Kareken, John, and Wallace, Neil. 1981. On the indeterminacy of equilibrium exchange rates. Quarterly Journal of Economics 96 (May): 207-22.

King, Robert G.; Wallace, Neil; and Weber, Warren E. 1992. Nonfundamental uncertainty and exchange rates. Journal of International Economics 32 (February): 83-108. 
Lucas, Robert E., Jr. 1982. Interest rates and currency prices in a two-country world. Journal of Monetary Economics (November): 335-60.

Morrill, James R. 1969. The practice and politics of fiat finance: North Carolina in the Confederation, 1783-1789. Chapel Hill: University of North Carolina Press.

McCusker, John J. 1978. Money and exchange in Europe and America, 1600-1775: A handbook. Chapel Hill: University of North Carolina Press.

Nevins, Alan. 1927. The American states during and after the Revolution, 1775-1789. New York: Macmillan.

Perkins, Edwin J. 1992. Continuities and innovations: American public finance and financial services, 1700-1815. Manuscript: University of Southern California.

Schweitzer, Mary M. 1989a. State-issued currency and the ratification of the U.S. Constitution. Journal of Economic History 49 (June): 311-22. . 1989b. A new look at economic causes of the Constitution: Monetary and trade policy in Maryland, Pennsylvania, and Virginia. The Social Science Journal 26: 15-26.

Shell, Karl. 1977. Monnaie et Allocation Intertemporelle. CNRS Seminaire d'econometric de Roy-Malinvaud. Manuscript.

Smith, Bruce D. 1985a. American colonial monetary regimes: The failure of the quantity theory and some evidence in favor of an alternate view. Canadian Journal of Economics 18 (August): $531-65$.

. 1985b. Some colonial evidence on two theories of money: Maryland and the Carolinas. Journal of Political Economy 93 (December): 1178-211.

. 1988. The relationship between money and prices: Some historical evidence reconsidered. Federal Reserve Bank of Minneapolis Quarterly Review 12 (Summer): 18-32. 
Sylla, Richard. 1982. Monetary innovation and crises in American economic history. In Crises in the economic and financial structure, ed. Paul Wachtel, pp. 23-40. Lexington, Mass.: Lexington Books.

United States. Constitutional Convention. 1787. Jonathan Elliot's debates in the several state conventions on the adoption of the Federal Constitution as recommended by the General Convention at Philadelphia in 1787, vol III. Richmond, VA: James River Press.

Wallace, Neil. 1983. A legal restrictions theory of the demand for "money" and the role of monetary policy. Federal Reserve Bank of Minneapolis Quarterly Review 8 (Winter): 15-24.

Wicker, Elmus. 1985. Colonial monetary standards contrasted: Evidence from the seven years' war. Journal of Economic History 45 (December): 869-84.

Zarazaga, Carlos E. 1991. Hyperinflations and moral hazard in the appropriation of seignorage. Manuscript. University of Minnesota. 